\title{
1
}

\section{Rurality and rural space: the 'policy effect' of the Common Agricultural Policy in the Borders of Scotland}

\author{
John Gray
}

\begin{abstract}
A central aim of the European Union's Common Agricultural Policy (CAP) since its inception in the 1970s has been to sustain rural society, the landscape and the environment, particularly those areas with less favourable production conditions - that is, land with poor productivity, low production and declining populations. Since 2003, the European Union's CAP has undergone two major reforms, the aim of which is to ensure the vitality and sustainability of rural communities. The first focuses on market-related support and direct aid to farmers for agriculture, including the Less Favoured Area Support Scheme. The second focuses on broader rural development including diversification of economic activities and stewardship for the environment. The aim of this chapter is to trace changes in rural land use and landscapes on hill sheep farms that result from the policy effect of the CAP: the dialectic evolution of the concept of rurality embedded in the European Union's CAP and the rural landscapes shaped and used by hill sheep farmers in the Scottish borderlands.

\section{Introduction}

This chapter is a case study of the relationship between agricultural policy and human activity as it is manifest in rural landscapes and concepts of rurality. The particular case I analyse is the European Union's Common Agricultural Policy (CAP) and the activities and experiences of hill sheep farmers in the Scottish borderlands. My aim is not just an analysis of the production of rural space in this particular locality but a more general understanding of rural space/landscapes (in Australia, Europe and North America) as materialisations of policy-motivated formulations of rurality by governments (whether local, national or supranational) and practically generated activities of those living in the locations deemed to be rural by the policy. One of the characteristics of this dialectic of government policy and local practice is what Bourdieu calls 'the theory effect':
\end{abstract}


Due to the existence of a social science, and of social practices that claim kinship with this science, such as...the conduct of politicians or governmental officials...there are, within the social world itself, more and more agents who engage in scholarly, if not scientific, knowledge in their practices and more importantly in their work of production of representations of the social world and of manipulating these representations. So that science increasingly runs the risk of inadvertently recording the outcome of practices that claim to derive from science. (Bourdieu 1992:249-50)

In the case presented here, I am illustrating an analogous 'policy effect': the representations of and policies for rural spaces devised by the European Community in its CAP set the conditions for hill sheep farmers to produce in their practices a concrete rural locality as a version of the rurality represented in the CAP. The CAP records these mediated effects on agriculture and rural landscapes of its policy in its analysis of the nature of rural spaces within the European Community for which it has to devise further representations and concomitant policies. In addition, not just a mutually entailed emergence of policy and practice, the production of rural space/landscapes in the European Union is also a dialectic of rurality as locality and rurality as representation.

\section{Rural image/rural locality}

In a survey of academic definitions of the 'rural', Halfacree (1993:32) posits a distinction between rural as locality and rural as social representation. As locality, rurality is a specific type of space that has a concrete geographical location where its character is objectified in the physical and social attributes of that location. In this mode, rural locations can be observed, analysed and mapped in various terms: topographical attributes, the social composition of the people living and/or working there, forms of activity, the nature of social relations and relations with other spaces of similar or different type in other geographical locations. In the mode of social representation, rurality is a de-spatialised cultural concept that has a 'disembodied and virtual character' because it is not linked to a concrete geographical location and thus it 'lacks empirical clarity' (Halfacree 1993:32). Instead, it is a discourse about a type of space that is usually morally charged and about the kind of social life that occurs in it. Often it includes landscape images, either visual or verbal, placing the rural at a distance and thereby presenting idealised pictures of society that are implied by but can never be attained in everyday life (see Hirsch 1995:9, 23). In this mode, the rural is something expressed rather than observed, interpreted rather than explained. It is related culturally (by meaningful contrast and similarity of image) to other representations of other types of spaces, particularly those of urban space (see Williams 1975; Creed and Ching 1997). 
Since its inception in 1958 and throughout its ensuing development in the next five decades, the CAP has conflated these two modes of conceiving rurality, alternately adopting them first in producing agricultural policy on the basis of an image of rurality and then in analysing the concrete rural localities that are its effects. A third form of rurality mediates this dialectic of image and locality: rurality as place. Here, I am referring to the way in which rurality is experienced and practised by rural people in their everyday activities. I illustrate this mode of rurality in the activities of hill sheep farmers as they respond strategically to agricultural policy to maintain the economic and intergenerational viability of their farms.

I trace the development of the CAP from its inception as part of the Treaty of Rome establishing the European Community to the recent changes of the Agenda 2000 and Fischler II Reforms (2003). The development of the CAP is also a 'history' of the concept of rurality as it moves through its various forms - locality, representation, particular experience of place - in the progressive dialect of policymaking and agricultural practice through which rural space is produced.

My analytical location is a function of the timing of my ethnographic research among hill sheep farmers in Teviotdale, a locality of 15 farms that straddles an 18-kilometre stretch of the River Teviot from its source to the mill town of Hawick (see Figure 1.1). It is a landscape of a river valley surrounded by steep hills reaching 600 metres high at the watershed and gradually decreasing in height and density as one moves in a north-westerly direction towards Hawick. The farms range in size from 160 to more than 2000 hectares, carrying 400 to 4000 breeding ewes. Hill sheep farmers differentiated the physical terrain in terms of two categories of farmland. 'Out-bye' — rough grazing or hill land-is predominant in the locality. It is characterised by steep gradients, altitudes in excess of 300 metres, harsh weather, boggy soil and nutrient-poor vegetation. 'In-bye' — or park — are areas of lower-altitude flat fields that become increasingly prevalent nearer to Hawick. All farms in the valley have some of both types of land. The nine larger farms (more than 500ha) on the higher ground nearer the watershed have a greater proportion of hill land (more than 75 per cent) and the six smaller farms on generally lower ground have a smaller proportion of hill land (less than 50 per cent). I did fieldwork in Teviotdale from 1981 to 2001. It was during this period that I was able to describe how hill sheep farmers strategically implemented the contemporary policies of the CAP with which they were confronted. These policies reflected the CAP's representation of rurality during the 1960s and 1970s and the effects this had on rural landscapes before my fieldwork. Assuming the actions of hill sheep farmers that I have observed are indicative of how other farmers have responded to the CAP during the 1980s and 1990s, I describe how their activities and their effects on rural space/landscape have been recorded and objectified in the understanding of rurality on which the Agenda 2000 and Fischler II reforms of the CAP are based. 


\section{Rurality as agricultural}

Creating a unified European Community in the late 1950s and early 1960s from a context of national boundaries, wars and political fragmentation required a communal space and common meanings. Because of its importance for food supply, consumer costs and political importance, agriculture was the primary vehicle for the construction of European communal space and the integration of the member states (see Bowler 1985:10-12). ${ }^{1}$ Its three guiding principles were: 1) a single market, with no internal tariff protection imposed by member states, which allowed labour, capital and agricultural products to circulate freely throughout the community at comparable costs; 2) a community preference for agricultural goods backed by an external tariff on products imported into the community; and 3) a sharing of the financial burdens and benefits of the CAP by the community as a distinct entity, rather than by distributional procedures to and from member states.

\section{Figure 1.1 Teviotdale}

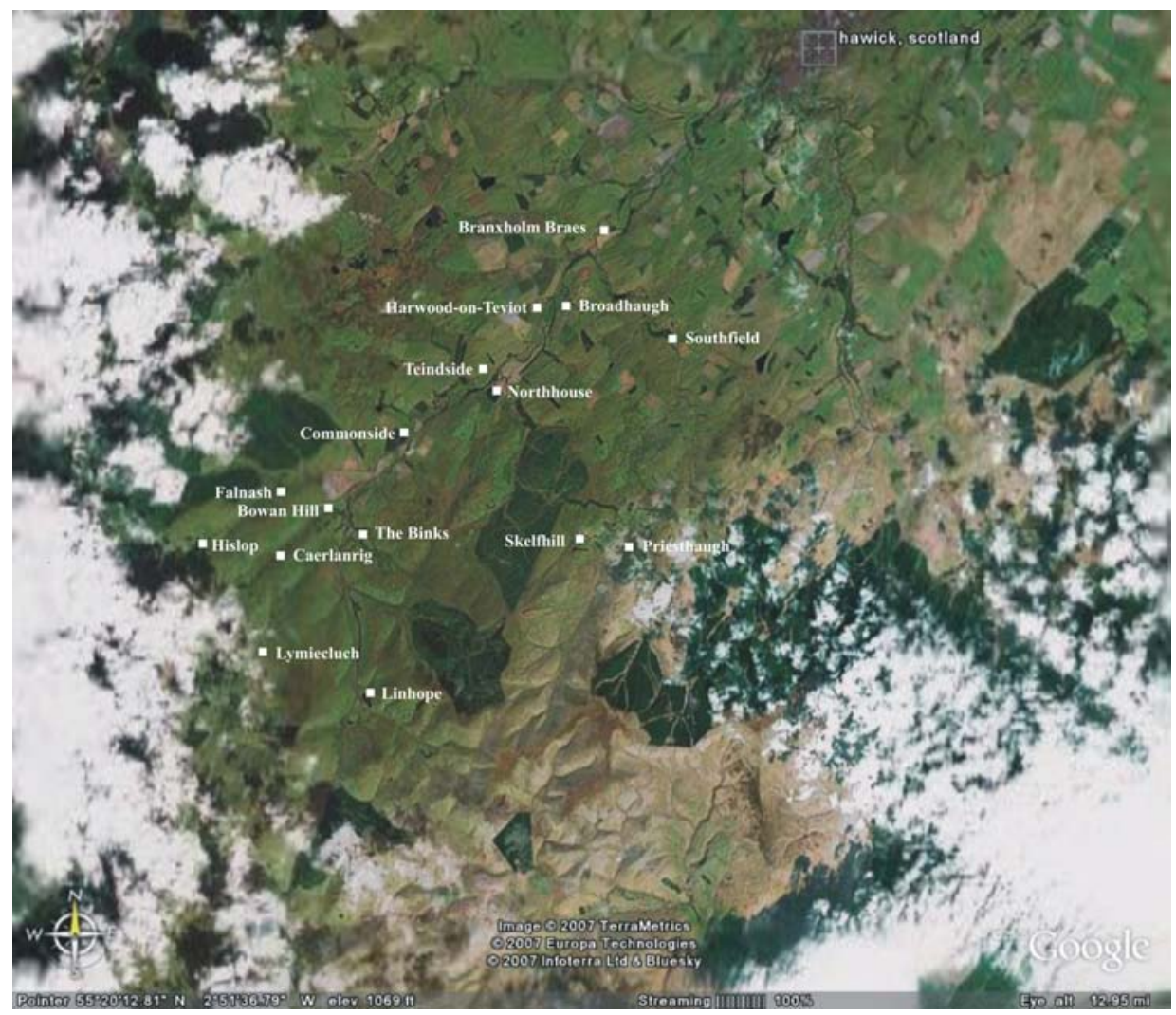


While these principles were overtly economic in character, they also identified the types of practices that would produce the internal nature and geographical limits of a distinct European space. The unified market, free internal movement of agricultural products and common prices and common financial responsibility de-emphasised the national partitioning of the European Community epitomised by pre-existing import levies of member states to protect their agricultural industry and by separate financial responsibility for their national agricultural sectors. Simultaneously, the uniform external tariff and the sharing of the financial burden of the CAP was the boundary that marked the limits of the European Community.

Within this European space, a major difficulty in formulating agricultural policy was the diversity of farming in member states in terms of resource endowment, the range and average size of farms, the density of population, the level of food self-sufficiency and the importance of agriculture in national politics. There were, however, two similarities on which a commonness could be 'codified' (see Bourdieu 1990:80) in formulating a European agricultural policy. First, all prospective member states had established tariff mechanisms to protect their farmers' incomes and their agricultural sectors from cheaper imported agricultural products and, remembering the privations during and after World War II, to maintain strategic self-sufficiency in food supplies. Second, in all member states there was an image of rural society portraying people and their agricultural way of life in the countryside that had cultural value and political significance. The five objectives of European Community's agricultural policy ${ }^{2}$ that emerged from these two points of convergence addressed issues of economic efficiency of the agricultural sector and stability of prices, political issues of national self-sufficiency of food supplies and reasonable prices for consumers, and social issues of the equitable distribution of income to farmers. The two most important objectives for understanding the effect of the CAP on rural landscapes and concepts of rurality relate to the incompatible aims of achieving social equity for individual farmers and promoting economic efficiency in the agricultural sector. With respect to the former, the Treaty of Rome set as an explicit objective for the CAP 'to ensure a fair standard of living for the agricultural population, particularly by increasing the individual earnings of persons engaged in agriculture' (Article 39[1b]). With respect to the economic efficiency of farming, the Treaty of Rome set the objective of increasing 'agricultural productivity by promoting technical progress and by ensuring the national development of agricultural production and the optimum utilisation of all factors of production, particularly labour' (Article 39[1a]). ${ }^{3}$

The social equity objective of maintaining farmers' standard of living was vital to an abiding goal of CAP - to preserve the image of rurality and the family farm as the major feature of agriculture that in turn was the condition for rural society - even if this inhibited the process of increasing economic efficiency in 
the agricultural sector. At the Stresa Conference in 1958, where the European Community's original objectives for agricultural policy were defined, it was explicitly stated that 'the structures of European agriculture were to be reformed and become more competitive, without any threat to family farms' (CEC [1958], quoted by Folmer et al. 1995:12; see also Pearce 1981:7). This implied causal link between family farming and the preservation of rural society continued to be central to the European image of rurality throughout the 1980s. The 1987 Green Paper, Perspective for the Common Agricultural Policy, states that its aim is 'to maintain the social tissue in the rural regions' by ensuring continued employment opportunities in agriculture. Moreover, the paper presents the community's image of rural space: 'An agriculture on the model of the USA, with vast spaces of land and few farmers, is neither possible nor desirable in European conditions, in which the basic concept remains the family farm' (European Commission 1985:II). The same aim and image of rural space were reaffirmed a year later in the European Commission's paper 'The future of rural society': 'This communication...reflects the Commission's concern to avoid serious economic and social disruption [caused by structural measures] and to preserve a European rural development model based on the promotion of family farms' (CEC 1988:67). ${ }^{4}$

In these statements, EC policy represented a rurality in which agriculture was the encompassing activity defining the nature and values pervading the whole of rural space. ${ }^{5}$ Rural space is a function of and is constituted by farming, family-based production units and a specific form of social life. While there is little specification of the attributes of farm, family and social life, family-based agriculture and rural society are portrayed as mutually constitutive: farming carried out by family production units is the condition for the kind of landscapes and social life characteristic of rural space (Marsh 1991:16) and rural space is the condition for and outcome of family farming.

This representation of ruralism as agricultural and vice versa is a version of 'rural fundamentalism', an urban-based and edifying image of agrarian society pervasive in the member states of the European Community at the time: 'farm people...were thought to make a special contribution to political, economic and social stability, economic growth and social justice' and the ownership of small parcels of land characteristic of the family-sized farm was considered to be 'the basis of a vigorous democracy' (Bowler 1985:16). ${ }^{6}$ In this image, agriculture, rural space and society are relatively homogeneous - it is where agriculture is carried out predominantly on small-sized farms managed by families. In addition, there is a causal relation between a specific form of agricultural production and exemplary society. Family farming creates the kind of space where rural society can flourish and where the ideals of wider society are nurtured and preserved. Family farming sustains not just rural society, but society as a whole, characterised by the ideals of stability, justice and equality. Thus despite the claimed academic marginality of such romantic representations of peripheral 
rural farming communities (Macdonald 1993:10-11), it was this morally charged image of rurality that was codified in the CAP. The link between material (agricultural) production and moral reproduction that is characteristic of this image of rural space continues through the progressive development of the CAP.

\section{Intensification and diversification of agricultural space/landscape}

In the 1970s and 1980s, the effect of the CAP's original market and price-support mechanisms on agriculture began to be analytically identified as two interrelated predicaments that threatened the viability of farming and rural society central to the image of rural fundamentalism. They derived from the CAP's conflicting aims of social equity and economic efficiency; paradoxically, the programs aimed at ameliorating them instead intensified them. The predicaments were known as 'the farm [income] problem' (Bowler 1985:46-8; Garzon 2006:28, 42) and 'the rural problem' (Kearney 1991:126).

The farm problem refers to the effects of general economic processes on the agricultural sector, in particular the accelerating inverse relation between increasing agricultural production by farmers and slackening demand for food by consumers. On the one hand, as national economies in Europe develop in a context of slow population growth, consumers spend less of their increasing income on food. Thus growth of demand for agricultural products is less than growth in income. On the other hand, as farmers use more and more technology to increase agricultural production, the supply of food expands faster than consumer demand. This process suppresses the prices of agricultural commodities and the income of farmers. Low farm income, which threatens the viability of rural society, is one of the two central issues of the farm problem specifically addressed by the CAP. Since one of its goals is to ensure a fair standard of living for farmers by maintaining income equity with other sectors of the economy, market intervention mechanisms have been developed to prop up the prices farmers receive for their products. ${ }^{7}$ Because support prices were above those of the world market, however, there was a need to protect them by erecting a clear boundary around the European agricultural market with import duties. Thus a European space was created where family farms and rural society could flourish, even if 'artificially' in economic terms.

Since EC analysts defined the essence of the farm problem as overproduction, the second and more fundamental solution to the farm problem and the increasing financial burden of price-support mechanisms was to decrease the size of the agricultural sector. This was the central point of the review of the CAP carried out by Sicco Mansholt in 1968. He suggested decreasing the amount of land in production and decreasing the numbers of people engaged in farming. Such 'structural' changes would force small, economically inefficient farms (that is, family farms) to go out of business and allow their consolidation into larger 
productions units. As a result, there would be larger farms with fewer farmers producing a greater share of food required in the European Community, thus increasing their incomes. This type of 'resource adjustment' (Bowler 1985:47) requires people leaving the agricultural sector to look for employment in other sectors. Spatially, this has meant that people leave the place where agricultural production is carried out to look for work where industrial production occurs. As I have argued above, in the early years of the European Community, agricultural production was the essence and defining feature of rural space while industrial production served the same signifying function for urban space. The point, then, is that resource adjustment has a severe impact on the small, inefficient family farms and society that the CAP was designed to preserve. Structural adjustments caused depopulation of rural areas and jeopardised the financial health of small family farms; they led to the establishment of large, mechanised farms with absent owners and local managers - the 'vast spaces of land with few farmers' that the European Community found undesirable. The 'rural problem' (Kearney 1991:126) refers to these threats to the mutual dependence between small family farming and rural society brought about by structural adjustments in the agricultural sector.

\section{Producing rural localities}

In order to address the incompatible aims of preserving rural society and farmers' incomes on the one hand, and increase the economic efficiency of the agricultural sector on the other, the CAP in the 1970s and 1980s introduced three instruments: regional diversification, price-support mechanisms and structural measures. Regional diversification and price-support mechanisms exemplified the way in which the design of CAP instruments was based on the image of rurality as a mutually constitutive relation between agriculture and rural society and on the consequent analysis of agriculture in marginal agricultural areas, such as hill sheep farming in the Scottish Borders. The analysis runs as follows: because of the poor quality of the land there is inherent low productivity and poor financial returns; in turn, these characteristics of hill sheep farming mean fewer employment opportunities and less incentive to take it up as an occupation; further, while consumer demand for lamb is relatively constant, hill sheep farming is seasonal so that farmers sell their lambs when supply is high; this depresses demand, the prices farmers receive and the level of income they can expect. Together, these were the ways hill sheep farms manifested the 'farm problem', and they threatened the viability of rural society by causing depopulation in locations such as the Scottish Borders.

The implementation of all three measures required that real rural localities be identified and this necessitated engaging in theoretical practices (Bourdieu 1992:250) to define rurality 'objectively' in terms of measurable attributes of landscape, topography and spatial relations and in social attributes of farm size, 
family personnel and interpersonal relations. A principle means of doing this was the Nomenclature unités territorial statistiques (NUTS) developed in 1980 by the European Union to statistically compare regional units from the level of nation-state (level zero) to smaller regions (level three) (see Figure 1.2). On this basis, rural localities could be made real through mapping and analytical comparisons of demographic, economic and agricultural data. At first, rural regions were defined solely by population density (more than 100 people/square mile). This was later refined through the use of the Organisation for Economic Cooperation and Development (OECD) typology in which rural was differentiated from urban solely on the basis of population density (more than 150 people/square mile); within the rural areas, degrees of rurality were distinguished in terms of the percentage of the population living in rural communities, from less than 15 per cent to more than 50 per cent.

Through the farming practices of hill sheep farmers in the Scottish Borders, all three measures had the effect of transforming agricultural landscapes through regional diversification of agricultural space within the community, intensification of production and diversification of agricultural land.

\section{Less favoured area: regional diversification of rural space}

While the CAP defined a common space for the agricultural sector by de-emphasising internal national partitioning, the policy instruments created a different kind of internal partitioning. The community was divided into 166 NUTS 3 regions (CEC 1987) as a way conceptualising and ameliorating the effects of structural transformations on rural society. This NUTS 3 regional spatialisation was not based on the political differentiation of nations but on diversity in topography, resources and potential for development in rural areas. This marked an era of regional policymaking (Shucksmith et al. 2005; Bowler 1985:57) that was lacking in the original formulation of the CAP. For the Borders of Scotland, the most important of these regionalising polices was Directive 75/268, establishing Less Favoured Areas within the European Community (see Figure 1.3). The stated objective of the directive was, again, social rather than economic: to ensure the continuation of farming in areas characterised by poor natural resources for agricultural production and to maintain the density of the rural population in these areas. Less Favoured Areas were mountainous and hilly regions with marginal agricultural potential because of the topography and soil quality, low and declining population and/or poor infrastructure. They were also the localities where family farms were concentrated. 
Figure 1.2 NUTS regions of Scotland

SCOTLAND (NUTS 1 AREA): Breakdown to NUTS 2, 3 and LAU1 Areas

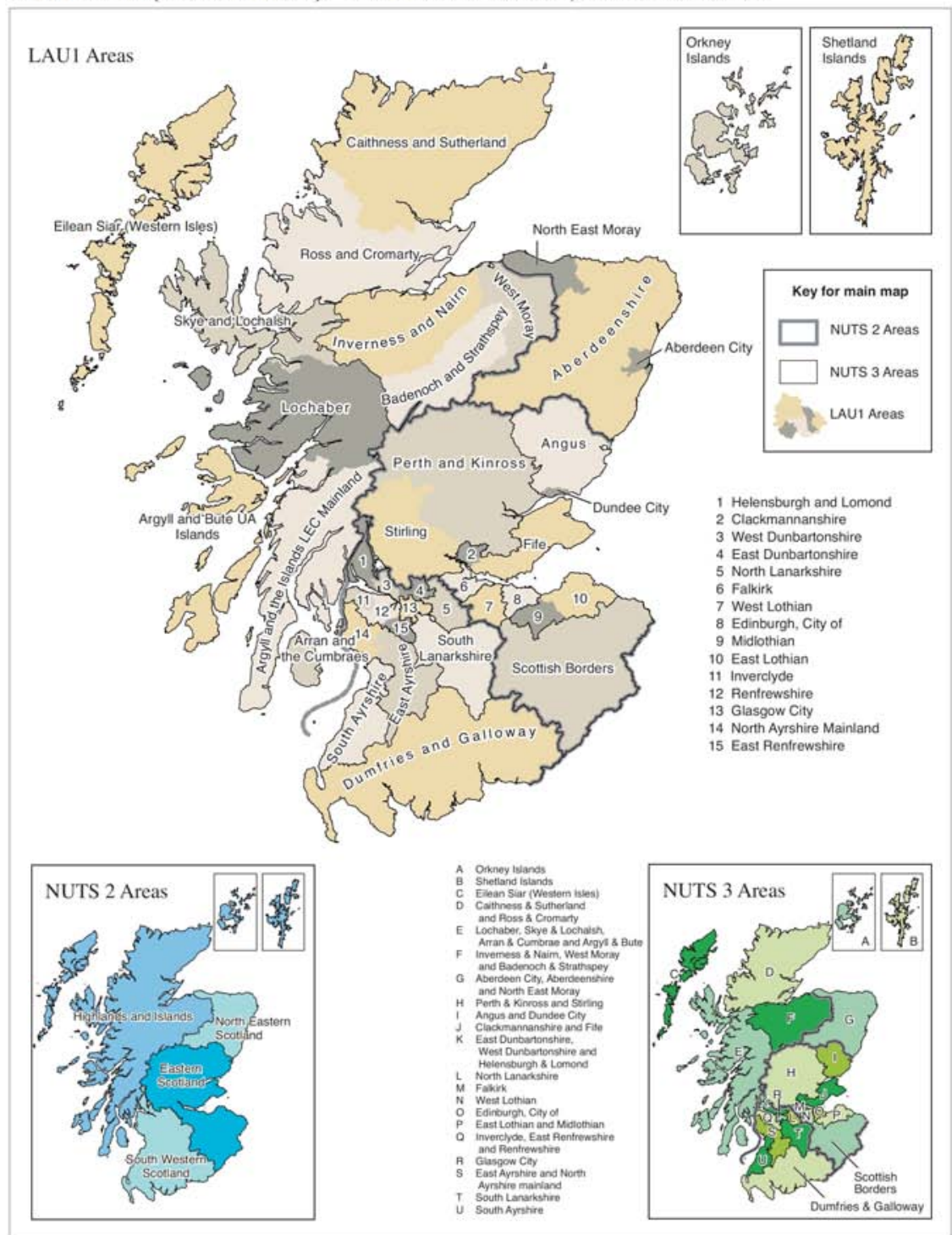


Figure 1.3 Less Favoured Areas, 1997, showing NUTS 3 regions

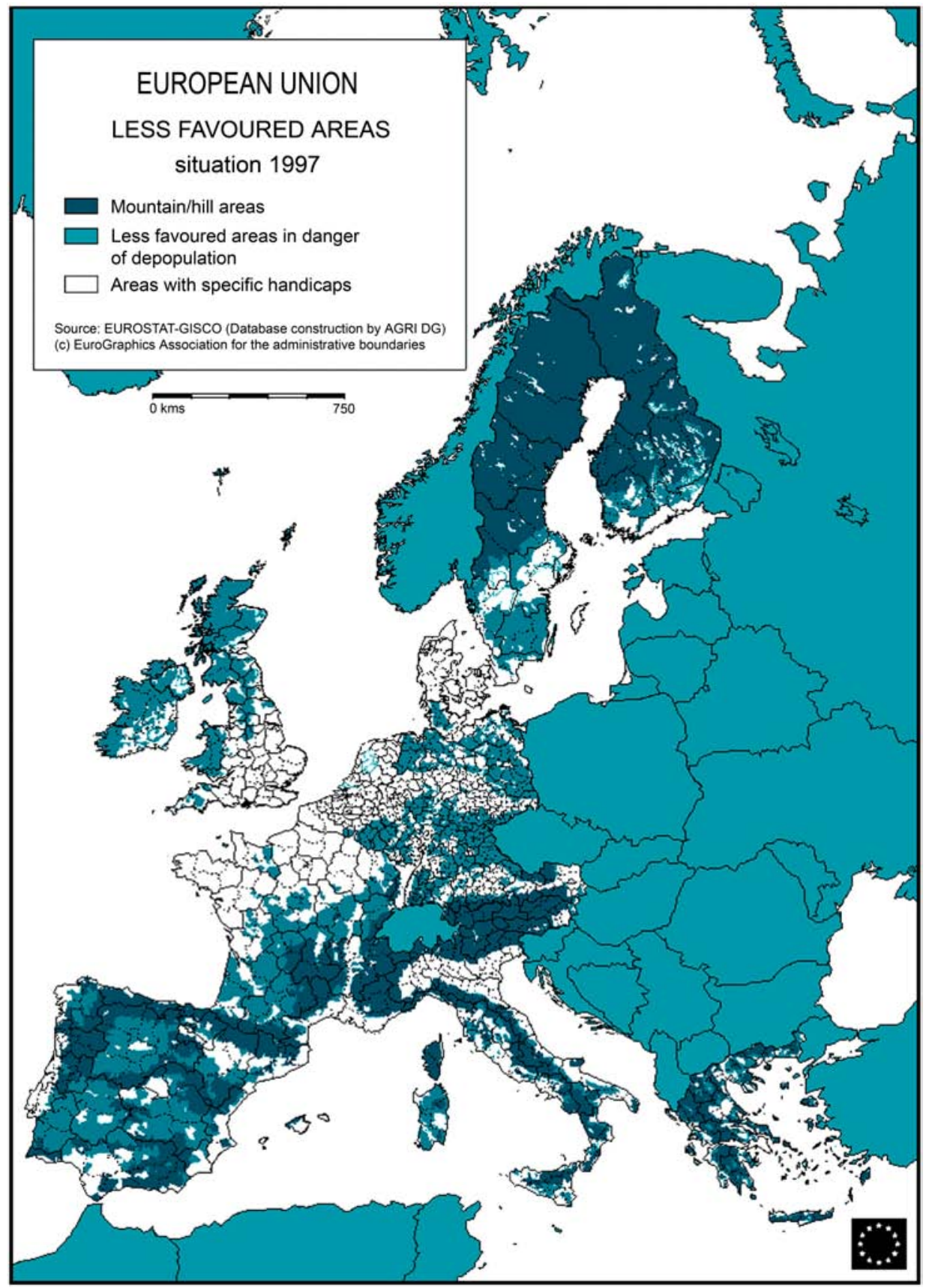


As a result of this directive, the hill sheep farming area of the Borders took on a specific spatial quality. As a Less Favoured Area, it was a productively marginal but still rural space for moral reproduction within the European Community that needed special assistance. It was necessary to differentiate this type of rural space because price-support mechanisms and structural measures by themselves were insufficient 'to sustain the traditional pattern of small-scale family farming in the Community and to encourage the continued population of some remote rural areas' (Marsh 1991:16). Thus farms in Less Favoured Areas were eligible for direct payments to compensate for the impediments to production imposed by the environment or caused by CAP instruments that were beyond the control of farmers. In the 1980s and 1990s, these payments, known as Hill Livestock Compensatory Allowance (HLCA), were targeted to directly increase farmers' incomes by being based on input (livestock numbers grazing on hill land) rather than on output, as were the price-support mechanisms. ${ }^{8}$ As a result, farmers were motivated to increase the numbers of stock on their land to increase the HLCA payment.

\section{Price-support mechanism: intensification of production}

The second type of measures adopted by the CAP to address the farm income problem and the concomitant rural problem and to preserve the localities where farming and rural society could flourish were market-intervention schemes. These worked by supporting the minimum prices individual farmers received for their products. The most important of these schemes for hill sheep farmers was the Sheep Meat Regime introduced in 1980. The Sheep Meat Regime was a 'variable premium' paid to farmers on their 'finished' or fat lambs. ${ }^{9}$ The variable premium supplemented the market price a farmer received up to a CAP-determined seasonally adjusted, weekly market price (the 'variable' component of the premium) that represented what farmers should receive for their lambs to realise a fair income level. In addition, the regime included a 'ewe premium' paid to farmers for every breeding ewe maintained on their farms. This headage payment was meant to fill the gap between the UK guide price and the EC-wide basic price for fat lambs. In Less Favoured Areas, the rate for ewes on severely disadvantaged hill land was twice the rate for ewes on better quality low-lying fields. Hill sheep farmers were unanimous in saying that without these two price supports, which represented at least 25 per cent of their turnover, hill sheep farming would not be viable.

The general effect of these price-support schemes on the agricultural sector was to (over)-stimulate farm production: the more products sold on the market, the more a farmer received in price subsidies and the greater the income; the more ewes on a farm, the greater the total ewe premium received. They represented nearly 90 per cent of the CAP budget. This reflects the importance to the 
European Community of rural space and the link between material production in agriculture and moral reproduction in social life.

\section{Structural measures: diversification of agriculture}

In order to achieve economic efficiency in agriculture, the CAP adopted structural measures or resource adjustments. These were aimed at controlling the productive capacity of the agricultural sector so that the supply of agricultural products matched the demand for food in the European Community. Structural measures involve decreasing the amount of land in agricultural production, increasing the size and technology input of farms in order to take advantage of economies of scale and transferring labour and capital from farming to other sectors of the economy. The two structural adjustment schemes that were used by almost every Borders hill sheep farmer during the 1980s were the Agricultural Development Scheme (European Community) and the Agricultural Improvement Scheme (United Kingdom). These grant schemes provided financial support for modifying the natural qualities of agricultural land, particularly the marginal land in Less Favoured Areas, as a means of increasing the efficiency of labour and the product efficiency of the farm. This is explicitly conveyed in an explanatory leaflet:

The aim of an improvement plan is to bring about a lasting and substantial improvement in the economic situation of your farms. The plan must therefore show that, within a period of not more than 6 years, the investments you propose to make will increase the earned income of each labour unit needed to run the business. (Department of Agriculture and Fisheries for Scotland 1986:1)

Grants, which in the Less Favoured Areas can cover up to 60 per cent of the costs, are given to assist in a wide variety of expensive and technologically based improvements to hill pasture: planting shelter belts; building and repairing stone dykes and fencing for controlled grazing and lambing; spraying bracken to improve the pasturage on hills; building roads for improved access to hill grazing areas for delivery of supplementary feeding; building sheds to house ewes during lambing; and, most important of all for hill sheep farmers, installing land drainage, reseeding and regeneration of grassland for permanent high-quality pasturage. These schemes were designed to improve the economic viability of farms by increasing labour productivity, maximising profit and maintaining rural society.

The way hill sheep farmers used these programs led to a diversification of agricultural practice and rural landscape within and between their hill sheep farms. Those farms with a high proportion of rugged hill land that could not be converted into improved pasture were unable to switch production from purebred hill lambs to crossbred field lambs. Since hill lambs are often too small 
to meet fat-lamb certification standards, they were sold on the store market where they were not eligible for the variable premium. While these farms used grants to convert as much land as possible to increased lamb production on improved pasture and used supplementary feeding to fatten more of their hill lambs, they largely remained 'breeding' farms in the sense that the majority of their production was purebred hill lambs sold on the store market. Those farms that had a greater proportion of low-lying hill land and flat fields converted the former to improved pasture where they could raise less hardy but more prolific field sheep and where the larger lambs could be fattened to the certification standards of the Sheep Meat Regime. These farms sought to increase the production of crossbred fat lambs that were eligible for the variable premium. They were labelled 'commercial' farms because there was less emphasis on breeding programs for purebred hill sheep and more emphasis on feeding programs for crossbred field sheep.

The CAP's representation and analyses of and policies for rural spaces within the European Community that I have described thus far were thoroughly agricultural and focused on issues of production (see also Ward and McNicholas 1998:28). Regions in the European Community were defined in terms of their economic dependence on agriculture, policy issues within these regions were seen to emerge from the 'farm problem' and the 'rural problem', and the mechanisms devised to deal with these issues - price supports and structural measures - were targeted at agricultural production. Further, the Less Favoured Area directive was aimed at propping up with direct income support farming in areas of marginal potential for agricultural production where small inefficient family farms tended to predominate. These policies are consistent with a representation of rurality in which rural space and society are a function of, constitute and are encompassed by agriculture, particularly family farms. In the next phases of the process, there is a significant change in the representation such that rurality becomes autonomous from and encompasses agriculture. This leads to a shift from agricultural policy to rural development policy in which rural space becomes a location for consumption rather than primarily for agricultural production.

\section{Diversification of rural space}

In the late 1980s and throughout the 1990s, the European Community began to revise the representation of ruralism and the revisions appeared to appropriate the changes the CAP had wrought on rural locations: regional diversification of rural space, intensified production and agricultural diversification. I begin my analysis of this newly formulated representation of ruralism with the 1988 European Community Commission report, 'The future of rural society'. This report is a reflective portrayal of rural space that describes the effects of the CAP on farming (brought about by the actions of farmers in appropriating policy 
measures into their farming practices), the current problems facing rural society and strategies for addressing these problems.

The report begins with the following description of rurality, which I quote at length not only because it highlights the emerging autonomy of ruralism from agriculture and the different types of spaces that now exist within it, but because it still recognises: 1) the need to support farming in rural areas to offset the effects of structural change on rural society; and 2) the mutually constitutive relation between human activities in rural space and forms of social life- a more general version of rural fundamentalism.

The concepts of the countryside or of rural society are by no means merely geographic in scope, since economic and social life outside our towns and cities is of great complexity, embracing a wide range of activities... (CEC 1988:5)

Rural society [as locality], as it is generally understood in Europe, extends over regions and areas presenting a variety of activities and landscapes comprising natural countryside, farmland, villages, small towns, regional centres and industrialised rural areas. It accounts for about half of the population and a little over $80 \%$ of the territory of the Community.

But the concept of rural society [as representation] implies more than geographical limits. It refers to a complex economic and social fabric made up of a wide range of activities: farming, small trades and businesses, small and medium-sized industries, commerce and services. Furthermore, it acts as a buffer and provides a regenerative environment which is essential for ecological balance. Finally, it is assuming an increasingly important role as a place of relaxation and leisure.

[After the expansions of the European Community in 1973 and 1987,] the Community has acquired a distinctly higher proportion of areas the structures of which militate against proper economic-and social-development. Most of these areas are rural in the extreme, sometimes with $20-30 \%$ of the population still employed in farming. (p. 15)

Notable in this description is the change in the relation between agriculture and rurality. Agriculture exists within and is encompassed by rural space and society rather than the other way around, as it was in the earlier representation. This change foreshadows a major theme of the report: the decrease in the importance of agriculture in rural regions. It proposes an urban-centric spatial model that identifies three types of rural regions. Each of these regions is defined by its relation to large conurbations; each is described as experiencing a different problem brought about by the overall decrease in the importance of agriculture within the European Community; and together these are referred to in the report 
as the 'three standard problems' (CEC 1988:28-9). First, there are areas close to cities experiencing 'the pressure of modern life' due to an influx of population and competition for the use of land where agriculture is least important and where there is a diversification of land uses between agriculture, industry and leisure. Second, there are 'outlying regions' experiencing 'rural decline' due to out-migration where agriculture remains relatively important but with decreasing employment opportunities because of technological improvements in production. Third, there are the 'very marginal areas' experiencing more marked rural decline and depopulation where agriculture remains the most important sector of the local economy and where there is little potential for economic diversification because of the difficulty of providing services and infrastructure. The second and third standard problems portray rural areas experiencing what Kearney earlier called the 'rural problem' (1991:126). In this sense, the report appropriates into its revised representation of rural space the effects of the structural adjustments brought about by the implementation of the CAP.

The last paragraph of the quote is also significant to the revised representation of ruralism. It describes a reconfiguration of the relation between agriculture based on family production units and rurality. Now in relation to the large, technologically advanced agribusiness farms, leisure areas and environmental buffer zones, the spaces 'furthest from the mainstream of Community life' (CEC 1988:7) - where small family farming of the rural fundamentalist image continues - are 'rural in the extreme': remote, depopulated and economically marginal because of their heavy dependence on agriculture. The word 'extreme' is important in the paragraph because it is a narrative form of distanciation as well as authenticity. Its use makes poorer agricultural regions, the Less Favoured Areas like those of the hill sheep farming area of the Scottish Borders, into a kind of distanced and marginal landscape - a museum-like place portraying the original image of rural space where family farming and a valued form of society continue to exist.

Overall, then, 'The future of rural society' records the marginalisation of agriculture-especially small family-based farming-into the European Community's revised representation of rurality. Unlike the original 'agrarian' (Bonanno 1991) configuration, rurality is now portrayed as incorporating heterogeneous activities and types of spaces. The nature of rural space is not defined only by agriculture, even a diversified agriculture. Instead, the rural is also a place for small industry and leisure activities in those areas where structural adjustment mechanisms of the CAP have lead to a rural decline; and it is also a place for environmental preservation in those areas where the price-support mechanisms have led to farmers adopting intensive but ecologically damaging methods of agricultural production as a means of maximising income from subsidies. This representation of rural areas for leisure and environmental preservation continued the moral-reproductive function of the earlier rural 
fundamentalist image that the CAP originally envisioned for farming in rural society. In the former case, there is rural space for relaxation and recreation necessary for regenerating the human spirit for people throughout the entire European Community; and, in the latter case, there is rural space for regenerating the environment essential to the ecological balance of the entire community. Rural locations should be preserved not just for the farmers living there but for the benefit of society as a whole.

Another implication of representing the rural as constituted by a diversity of activities and spaces is that it also has a diversity of endogenous resources - not just land for agriculture - that can be developed to expand and reinvigorate the economy and society of rural areas. Instead of local farmers relying on CAP price-support mechanisms to produce agricultural commodities for people outside their rural locality, rural localities are now places that people from outside come into to consume the diversity of things that now constitute rural localities: the environment, heritage, beautiful natural landscapes, local customs and artefacts.

\section{Agenda 2000 and beyond}

I am now moving into a period of CAP policy development and the changes in the measures designed to achieve the aims of the reformed CAP that occurred after my last period of fieldwork among hill sheep farmers in 2001, just before the outbreak of foot-and-mouth disease. Four farms in the fieldwork area had to destroy all their sheep and the others were quarantined throughout the outbreak. What follows, then, is suggestive of how these policy documents construct the nature of rurality and an image of rural landscapes. It also sets a framework for future research into the way in which hill sheep farmers have practically adopted these policy measures together with the effects of the 2001 outbreak of foot-and-mouth disease.

To achieve the development of rural regions, the European Commission produced a number of documents that transposed the image of diversified rurality into tangible localities exhibiting characteristics of the pressure of modern life, rural decline and very marginal areas and exemplifying the mediated effects of previous agricultural policies. All of them envisioned a phasing out of price-support schemes and placed a revised CAP within the broader agenda of integrated rural development. This is a shift from a sectoral approach of assisting agriculture throughout the European Community to a more territorial approach supporting agricultural, infrastructural, educational, social and economic development in specific localities. The principal analyses and policy statements are: the MacSharry Reforms (1992), the Community Initiative for Rural Development (LEADER), the Cork Declaration (1996), the Buckwell Report (1997), culminating in Agenda 2000 (July 1997). 
Agenda 2000 identified four aims for the CAP. First, 'ensuring continued agricultural land use and thereby contributing to the maintenance of a viable rural community; note here the continuing importance of agriculture to the viability of rural communities'. Second, 'preserving the countryside'. Third, 'maintaining and promoting sustainable farming systems'. Fourth, 'assuring environmental requirements'. Agenda 2000 also re-conceptualised the CAP as based on two 'pillars'. Pillar one includes market and price mechanisms to support agricultural production. Pillar two consolidates various programs and mechanisms that contribute to rural development, including economic diversification, infrastructural improvement, rural heritage, protection of the environment, maintenance of the countryside, restoration of landscapes, extensification, and set-aside. Less Favoured Areas continue in the CAP, now explicitly as a component of Rural Development (pillar two), not only because of the impact of the poor land on agricultural production and the decline in farming and rural populations, but because of the environmental 'high nature value' of Less Favoured Area landscapes. As a result, rural areas are now like areas of European nature conservation interest - in fact, the two types of areas have large expanses of overlap (see Figure 1.4).

A common theme in these policy statements and reports culminating in the Agenda 2000 reforms is a reiteration of the effects that previous measures, particularly price-support schemes such as the Sheep Meat Regime and support through the Less Favoured Areas policy, have had on rural localities: overproduction, polarisation of incomes between small family farms and large technologically based farms, environmental degradation and continued rural decline. Based on this analysis, Agenda 2000 stated the objectives for a reformulated CAP for 2000-06. They incorporated the original aims identified in the Treaty of Rome of achieving social equity for farmers and promoting economic efficiency with new aims of environmental management and multidimensional rural development to maintain the viability of rural society:

ensuring a fair standard of living for the agricultural community and contributing to the stability of farm incomes; increased competitiveness internally and externally in order to ensure that EU producers take full advantage of positive world market developments; food safety and food quality which are both a fundamental obligation towards consumers; integration of environmental goals into the Common Agricultural Policy; and creation of alternative job and income opportunities for farmers and their families. (European Commission 1997b) ${ }^{10}$ 
Figure 1.4 Less Favoured Areas (LFAs) and areas of European nature conservation interest (EECONET) in the European Union

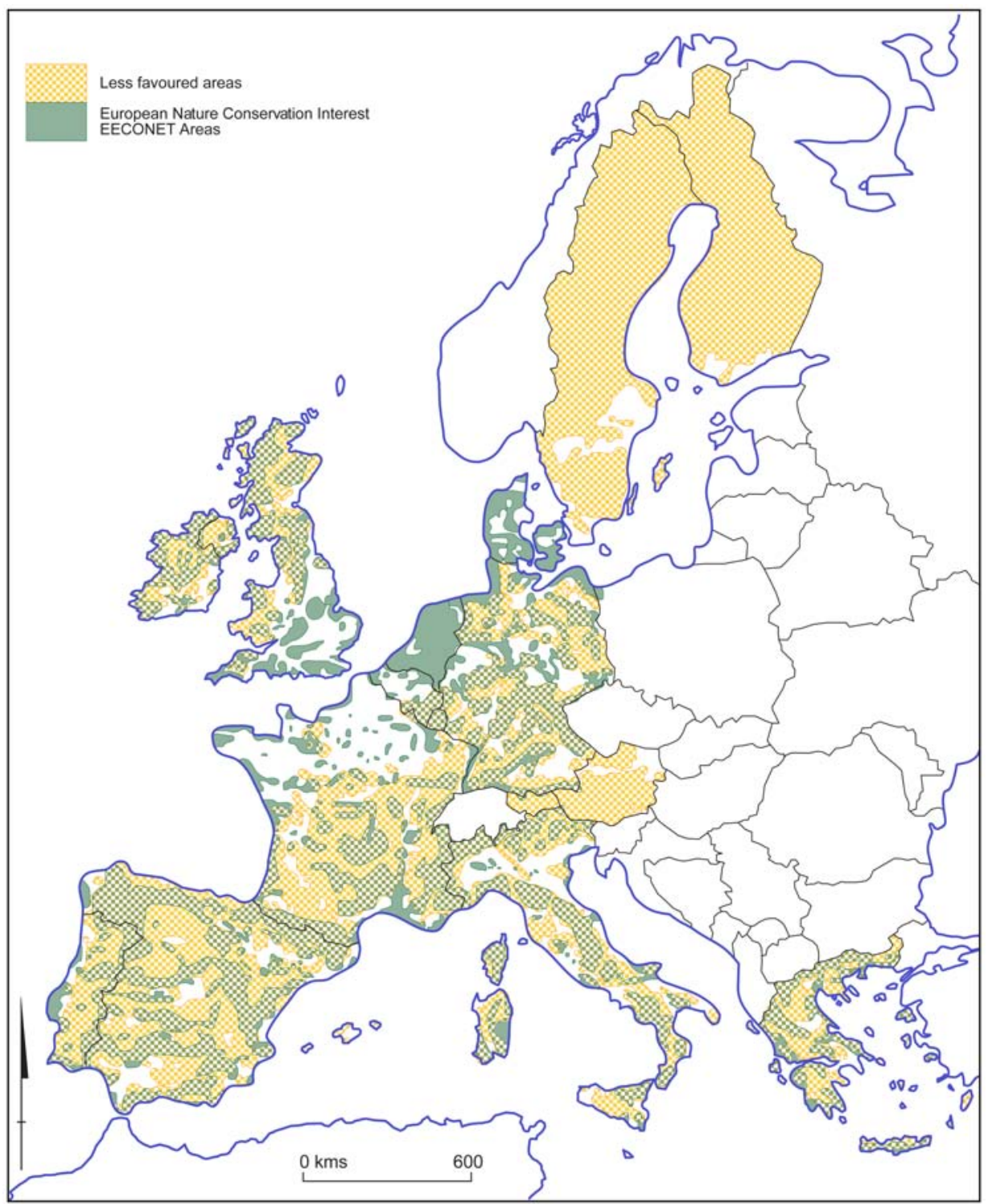

Source: EECONET. 
Figure 1.5 Objective one and objective two areas of the European Union

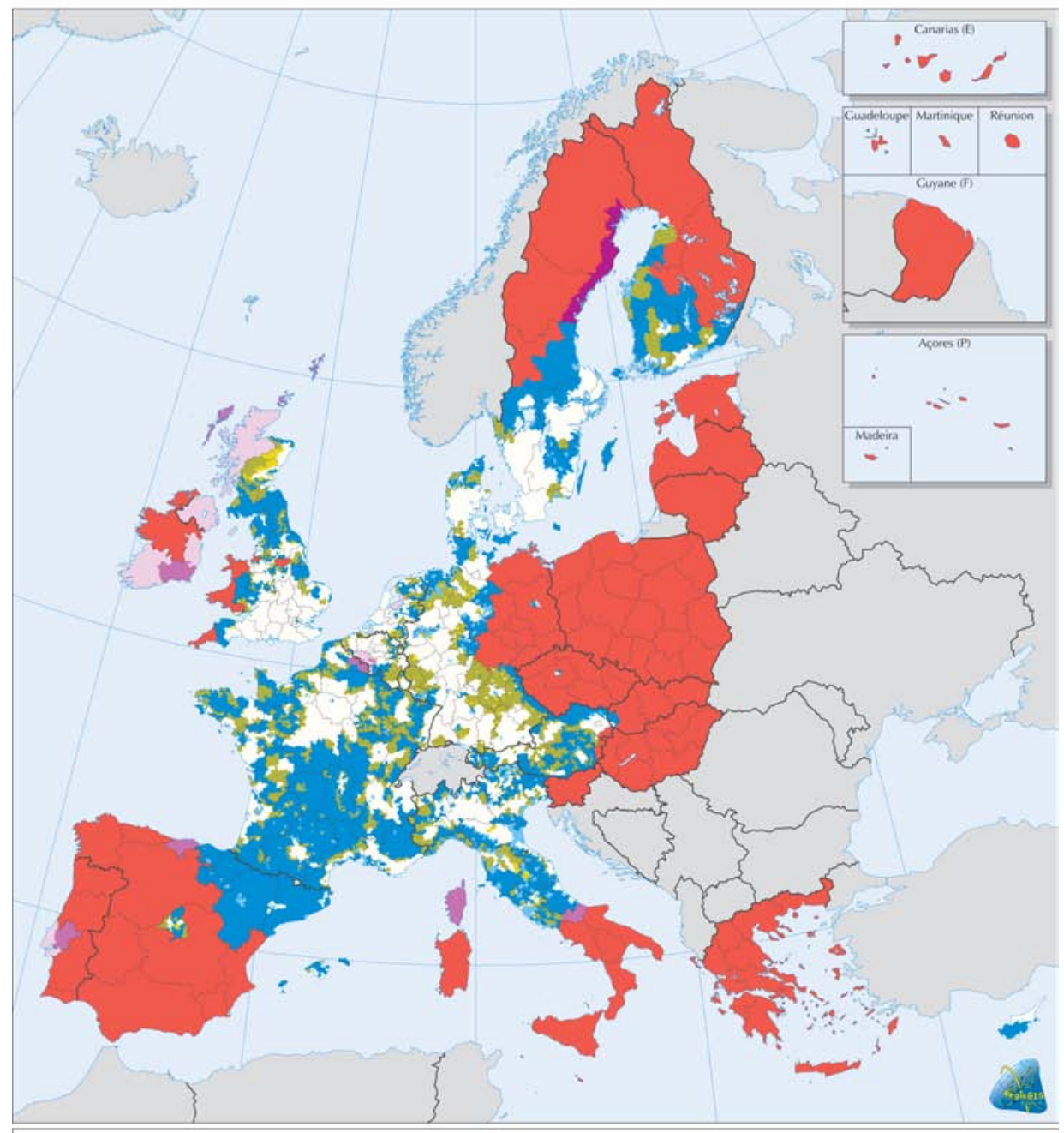

Structural Funds 2004-2006: Areas eligible under Objectives 1 and 2

Objective 1

Objective 1

Phasing-out (till 31/12/2005)

Phasing-out (till 31/12/2006)

Special programme
Objective 2

Objective 2

Objective 2 (partly)

Phasing-out (till 31/12/2005)

Phasing-out (partly) (till 31/12/2005) 
In the Explanatory Memorandum accompanying Agenda 2000 (European Commission 1997b), the 'European model of agriculture' is explicitly described as competitive, using environmentally friendly production methods and including a diversity of agriculture 'rich in tradition... [and seeking] to maintain the visual amenity of our countrysides [sic] as well as vibrant and active rural communities' (European Commission 1997b, Explanatory Memorandum:5). Again, as in the 1987 Green Paper, there is an explicit juxtaposition of European agriculture with Europe's major competitors (that is, the United States), particularly the part it plays 'in society and in preserving the landscape, whence the need to maintain farming throughout Europe and to safeguard farmers' incomes' (European Commission 1997b, Explanatory Memorandum:6).

All payments to farmers under the CAP were dependent on their compliance with ('cross-compliance') requirements to maintain their land in good agricultural and environmental condition including appropriate stocking densities on the land, and to ensure plant and animal health, environmental protection and animal welfare. Recognising the consequences of price supports on inputs (that is, headage payment on stock) for intensification and overproduction, financial support under the Single Farm Payment Scheme for achieving these aims was now to be made on a land-area basis. In recognition of the detrimental environmental effects of intensive production, area-based direct support payments were linked to requirements for farmers to use the land less intensively in order to preserve the high nature value of landscapes in the Less Favoured Areas (European Commission 1997a:20).

In order to achieve these policy aims in the 2000-06 period, European space was re-spatialised to reflect the three priority objectives for the use of structural funds under Agenda 2000. Two of them address the development problems in remote areas (objective one) and rural areas facing a decline in traditional activities (objective two) - that is, agricultural activities in the Scottish Borders, by providing financial assistance for the creation of the heterogeneous activities and spaces now represented as constitutive of rurality. As a result, rural regions are now defined in 'objective' terms. The pun - referring to the objectives for the structural funds and to the mode of defining and identifying real locations of such ruralities in terms of objective measures such as population density-is here intended. In the first sense of objective, rural localities are theoretically characterised using a combination of the OECD measure of population density at local and regional levels and the Eurostat approach of measuring the degree of urbanisation by population density. On this basis, the European Community is divided into 'predominantly rural regions' (about 10 per cent of the population covering about 47 per cent of the European Community's territory), 'significantly rural regions' (about 30 per cent of the population and 37.4 per cent of the community's territory) and 'predominantly urbanised regions' (about 60 per cent of the population and 15.6 per cent of the community's territory). The 
geographical reality of these regions is attested to by the maps included in the report, which objectify the characteristics of rural localities and spatialise the community into tangible geographical spaces according to population density, degree of urbanisation and rural and urban regions. In the second sense of objective, these rural spaces are then assessed in terms of criteria relevant to each of the three objectives for the use of structural funds. On this basis, maps are produced that spatialise the European Community into tangible geographical regions that objectify these problems; it is these regions that qualify for structural funds to support rural development (see Figure 1.5).

\section{Conclusion: future research}

My description has chronicled revised representation of rurality as incorporating heterogeneous types of spaces and activities, and has summarised policies and mechanisms for implementation that objectify resulting images as concrete rural localities. Only one of these activities, now in decline, is agriculture. I have now reached the limits of my analysis. The next step is to conduct further ethnographic research in Teviotdale. As I mentioned previously, Teviotdale was also part of the area infected with foot-and-mouth disease in 2001. These two events provide a complex context within which hill sheep farmers have adapted their farming practices. My aim for my next period of fieldwork in Teviotdale is to find out what has happened to its rural landscape and society as a result of the way hill sheep farmers have appropriated the reformed policies and mechanisms into their farming practices, and the effects on their sense of what it means to live on family farms in a rural place.

\section{Bibliography}

Bonanno, A. 1991, 'From an agrarian to an environmental, food, and natural resource base for agricultural policy: some reflection on the case of the EC', Rural Sociology, vol. 56, no. 4, pp. 549-64.

Bourdieu, P. 1990, In Other Words: Essays towards a reflexive sociology, Stanford University Press, Stanford.

Bourdieu, P. 1992, 'The practice of reflexive sociology (the Paris workshop)', in P. Bourdieu and L. J. D. Wacquant, An Invitation to Reflexive Sociology, University of Chicago Press, Chicago.

Bowler, I. 1985, Agriculture Under the Common Agricultural Policy: A geography, Manchester University Press, Manchester.

Creed, G. W. and Ching, B. 1997, 'Recognizing rusticity: identity and the power of place', in G. Ching and G. W. Creed (eds), Knowing Your Place: Rural identity and cultural hierarchy, Routledge, London. 
Department of Agriculture and Fisheries for Scotland 1986, Agricultural improvement scheme, improvement plans, Explanatory Leaflet, Leaflet AIS (EC) 1, 1986.

Dumont, L. 1980, Homo Hierarchicus: The caste system and its implications, University of Chicago Press, Chicago.

European Commission 1985, Perspectives for the CAP, COM (85) 50 Final, 30 January.

European Commission 1997a, CAP 2000, Directorate General VI, viewed 15 January 1999, <http://europa.eu.int/comm/dg/new/cap2000/index_en.htm>

European Commission 1997b, Commission Orientations: Agenda 2000 - Agriculture, Directorate General VI, viewed 15 January 1999, <http://europa.eu.int/comm/dg06/ag2000/sum/sum_en.htm>

European Community - Commission (CEC) 1987, The Regions of the Enlarged Community: Third periodic report on the social and economic situation and development of the regions of the community, Office for the Official Publications of the European Communities, Luxembourg.

European Community - Commission (CEC) 1988, 'The future of rural society', Bulletin of the European Communities, Supplement 4/88, Office for the Official Publications of the European Communities, Luxembourg.

European Community - Commission (CEC) 1997, Towards a Common Agricultural and Rural Policy for Europe: Report of an expert group, $<$ http://europa.eu.int/en/comm/dgo6/new/buck_en>

European Spatial Planning Observation Network 2005, ESPON Project 2.1.3: The territorial impact of CAP and rural development policy, $<$ http://www.espon.eu/mmp/online/website/content/projects/243/277/index_EN.html>

Folmer, C. et al. 1995, The Common Agricultural Policy Beyond the MacSharry Reform, Elsevier Science, New York.

Garzon, I. 2006, Reforming the Common Agricultural Policy, Palgrave Macmillan, New York.

Halfacree, K. H. 1993, 'Locality and social representation: space, discourse and alternative definitions of the rural', Journal of Rural Studies, vol. 9, no. 1, pp. 23-37.

Hirsch, E. 1995, 'Landscape: between place and space', in E. Hirsch and M. $\mathrm{O}^{\prime}$ Hanlon (eds), The Anthropology of Landscape: Perspectives and place and space, Clarendon Press, Oxford. 
Kearney, B. 1991, 'Rural society - disparities in incomes and alternative policies', in J. Marsh, The Changing Role of the Common Agricultural Policy: The future of farming in Europe, Belhaven Press, London.

Macdonald, S. 1993, 'Identity complexes in Western Europe: social anthropological perspectives', in S. Macdonald (ed.), Inside European Identities: Ethnography in western Europe, Berg, Oxford.

Marsh, J. 1991, 'Initial assumptions', The Changing Role of the Common Agricultural Policy: The future of farming in Europe, Belhaven Press, London.

Newby, H. 1979, Green and Pleasant Land: Social change in rural England, Penguin Books, Harmondsworth.

Pearce, J. 1981, The Common Agricultural Policy: Prospects for change, Routledge and Kegan Paul, London.

Shucksmith, M., Thomson, K. J. and Roberts, D. 2005, The CAP and the Regions: The territorial impact of the Common Agricultural Policy, CABI Publishing, Wallingford, Oxford.

Taylor, C. 1979, 'Interpretation and the sciences of man', in P. Rabinow and W. M. Sullivan (eds), Interpretative Social Science: A reader, University of California Press, Berkeley.

Ward, N. and McNicholas, K. 1998, 'Reconfiguring rural development in the United Kingdom: Objective 5b and the new rural governance', Journal of Rural Studies, vol. 14, no. 1, pp. 27-39.

Williams, R. 1975, The Country and the City, Paladin, Frogmore, St Albans, Herts.

\section{Endnotes}

l I use the term 'common' in the sense that Charles Taylor does in drawing a distinction between common and shared meanings: 'Common meanings are the basis of community. Intersubjective meaning gives people a common language to talk about social reality... what it meant here is something more than convergence. Convergence is what happens when our values are shared...But we could also say that common meanings are quite other than consensus, for they can subsist with a high degree of cleavage; this is what happens when common meaning comes to be lived and understood differently by different groups' (Taylor 1979:51, italics added).

2 The five objectives were: increasing agricultural productivity, ensuring a fair standard of living for farmers, stabilising markets, guaranteeing food security and ensuring reasonable prices for consumers.

3 These are only two of the five objectives of agricultural policy identified in the Treaty of Rome. They foreshadow larger policy initiatives, termed Pillar 1 and Pillar 2 in the Agenda 2000 reforms.

4 'The future of rural society' paper, however, puts this image in a new configuration of agriculture and ruralism.

5 The use of the term 'encompassing' follows Dumont (1980:239-45).

6 There is some support for Bowler's assertion of the persuasiveness of this image in Europe at the time when the CAP was being developed. His description of rural fundamentalism is reminiscent of William's (1975) historical analysis of the changing representation of the 'country' in English literature and of Newby's $(1979: 14,18)$ notion of rural Romanticism as British society's living 'museum' of its cherished 
values. In addition, Creed and Ching (1997:19) point to the notion of the 'romantic trope of the countryside as idyllic retreat' in America. Unlike Bowler, however, these analysts also identify the negative images and realities of living in rural society.

7 As we will see below, there was an explicit social policy to preserve rural society by ensuring that farmers as the pivots of rural society were maintained.

8 In the early 1990s, the Beef Special Premium was introduced. This was a headage payment for beef cattle. Since most hill sheep farms also carry some cattle, this was another important source of income. I do no more than mention this scheme because sheep are the most financially and socially important livestock for a hill sheep farm.

9 Fat lambs are ready for slaughter at the time of sale.

10 These objectives are presented in a different order in Agenda 2000. I have changed the order so that it accords with the order in which I list the aims of the reformulated CAP. 